\title{
EFFECT OF PRANAYAMA ON BLOOD PRESSURE AND HEART RATE IN PREMENSTRUAL SYNDROME
}

\author{
Rajni Goyal1, Puneet Raj Goyal2, Rajveer Garg ${ }^{3}$
}

${ }^{1}$ Assistant Professor, Department of Physiology, Gian Sagar Medical College and Hospital, Ramnagar, Patiala.

${ }^{2}$ Assistant Professor, Department of Radiodiagnosis, Gian Sagar Medical College and Hospital, Ramnagar, Patiala.

${ }^{3}$ Consultant, Department of Neurosurgery, IVY Hospital, Panchkula.

\section{ABSTRACT}

Premenstrual syndrome (PMS) also called PMT or premenstrual tension refers to the cyclic recurrence of a combination of distressing physical, psychological or behavioural changes, during the luteal phase of the menstrual cycle. It is suggested that there is altered autonomic activity in the late luteal phase of their endometrial cycle. Practice of breathing exercises like pranayama is known to improve autonomic function by changing sympathetic or parasympathetic activity.

AIM

The aim of study was to investigate the role of pranayama on blood pressure and heart rate in premenstrual syndrome.

\section{MATERIAL AND METHODS}

In this study, 50 females suffering from premenstrual syndrome between the age group 18-45 years having 28 to 34 days regular menstrual cycle were taken as subjects. In all the subjects, a baseline recording of heart rate, systolic blood pressure, diastolic blood pressure was done. Subjects were divided into 2 groups (Group A- control group, Group B- study group); subjects in group B underwent 3 months pranayama training. After 3 months, recording of HR, SBP, DBP in both the groups was again done.

\section{RESULTS AND CONCLUSIONS}

This study suggests that subjects in Group B have better control over their symptoms associated with PMS. We observed that in Group B, parameters showed a significant reduction when compared with their basal levels. Also the subjects in Group B showed significant reduction in high basal sympathetic activity in comparison with Group A.

\section{KEYWORDS}

Premenstrual Syndrome, Heart Rate, Systolic Blood Pressure, Diastolic Blood Pressure, Cardiac Output.

HOW TO CITE THIS ARTICLE: Goyal R, Goyal PR, Garg R, et al. Effect of pranayama on blood pressure and heart rate in premenstrual syndrome. J. Evolution Med. Dent. Sci. 2016;5(73):5335-5337, DOI: 10.14260/jemds/2016/1210

\section{INTRODUCTION}

Premenstrual syndrome is a major clinical entity affecting a large segment of female population.(1) Premenstrual syndrome (PMS) also called PMT or premenstrual tension refers to the cyclic recurrence, of a combination of distressing physical, psychological or behavioural changes during the luteal phase of the menstrual cycle that interferes with family, social or work related activities.(2) PMS is most common in women between age group of 25 to 45 years, having a history of depression and positive family history of PMS.(3) It is estimated that $50-80 \%$ of menstruating women experience some degree of physical and psychological premenstrual symptomatology and that $3-5 \%$ have symptoms of sufficient severity to disrupt social or psychological functioning.(4) Most women with PMS must have at least one prominent mood symptom and four other somatic symptoms for at least two consecutive cycles which include mild psychological symptoms, bloating, weight gain, breast tenderness, swelling, aches and pains, poor concentration, sleep disturbance and appetite change. It must be restricted to the luteal phase of the cycle, ceasing around menstruation and must not be present

Financial or Other, Competing Interest: None.

Submission 23-06-2016, Peer Review 28-08-2016,

Acceptance 02-09-2016, Published 10-09-2016.

Corresponding Author:

Dr. Rajveer Garg,

Gian Sagar Medical College,

B-009, Ramnagar, Patiala.

E-mail:dr.rg2482@gmail.com

DOI: $10.14260 /$ jemds/2016/1210 for at least one week between the onset of menses and ovulation.(5)

Research has proved that PMS is a stress-induced psychophysiological disorder and that stress is a cause of symptoms of PMS.(6) Symptoms of PMS are probably due to complex interaction of ovarian hormones, central neurotransmitters, and the autonomic nervous system. Suggested aetiologic theories of PMS include psychological abnormalities, nutritional deficiencies, aberrations in the renin-angiotensin-aldosterone axis, altered prostaglandin activity, hormonal imbalances, and changes in endogenous opioid peptide activity.(7) Although PMS is widely recognised, its aetiopathogenesis is not yet understood and it lacks definitive, universally accepted diagnostic criteria. It is proposed that the altered functioning of the autonomic nervous system in the late luteal phase could be associated with its symptoms.(8)

\section{OBJECTIVE}

The present study was planned to investigate the effect of pranayama on blood pressure and heart rate in premenstrual syndrome.

\section{MATERIALS AND METHODS}

50 females suffering from PMS between age group 18-45 years having history of regular menstrual cycle from 28-34 days were recruited for study. The study was conducted in Gian Sagar Medical College and Hospital, Ramnagar, Patiala. The subjects were divided into two groups. Group A ( $n=25)$ was a control group. Group B $(n=25)$ was study group in which 
subjects performed pranayama for 3 months. The technique of following pranayama were taught to the patients of group B and practised regularly for 3 months.

\section{Pranayamas Taught were}

- Nadi-shodhana pranayama: Patient was instructed to use right thumb for right nostril and right third finger for left nostril. He was told to close the right nostril and inhale deeply through left nostril to the count of 4 . Then, he was told to block both nostrils and hold the breath for 2 counts. This was followed by blocking of the left nostril and exhalation through the right nostril to the count of 4 . This act was repeated with the other nostril also. The time duration was at least $2 \mathrm{~min}$ at first, progressively increasing the duration up to $10 \mathrm{~min}$. (9)

- Chandra Bhedi pranayama: The patient was asked to close the right nostril, inhale through the left nostril. Then, he was told to close the left nostril and exhale through the right nostril without any pause. Time duration was at least for $2 \mathrm{~min}$ at first, progressively increasing the duration up to $10 \mathrm{~min}$. (10)

- $\quad$ Bhramari pranayama: The patient was asked to close eyes with four fingers over each eye and thumbs blocking the ears. Then, he was told to inhale deeply through both nostrils and with the mouth closed exhale through both the nostrils producing a continuous humming sound until the exhalation has exhausted. This was repeated for 10 cycles. (9)

- Omkar chanting: The patient was asked to inhale deeply with both nostrils followed by a loud chanting of sound of omkar from the mouth during exhalation in the ratio of a: 0 ; ma as $1: 4 ; 2$. This was repeated for 10 cycles. (11)

- After taking history, subjects were called for measurement of HR, SBP, DBP, 7 days prior to expected date of menstruation. These parameters were recorded at baseline and after 3 months of pranayama in both the groups. HR was measured from ECG using Cardiofax machine (Limb lead-II). Then RR interval was measured on ECG with a ruler, HR was calculated. BP recording was done by standard sphygmomanometer.

\section{STATISTICAL ANALYSIS}

Data were analysed using unpaired t-test for comparison of parameters between control and study group. The paired ttest was used for comparing parameters among the same group before and after pranayama. $\mathrm{P}$ value $<0.05$ was considered statistically significant.

\section{RESULTS}

In the present study, 50 females suffering from PMS between age group (20-40) years were divided into 2 groups. Group A (Control) and Group B (Study).

The subjects in Group B underwent 3 months pranayama training.

In table 1 , on comparing pre and post values of HR, SBP, DBP in Group A, statistically no significant difference ( $p>0.05$ ) was observed.

In table 2, in Group B (group performing pranayam), we observed that all the parameters showed statistically significant difference $(p<0.05)$ when compared with the basal levels. In table 3, when post-intervention mean value of $\mathrm{HR}$, SBP, DBP in Group A was compared with Group B, results were statistically significant $(\mathrm{p}<0.05)$.

\begin{tabular}{|c|c|c|c|}
\hline Parameters & $\begin{array}{c}\text { Baseline } \\
\text { Value }\end{array}$ & $\begin{array}{c}\text { 3 Months Post- } \\
\text { Intervention }\end{array}$ & P Value* \\
\hline $\begin{array}{c}\text { HR } \\
\text { (per } \\
\text { min.) }\end{array}$ & $81.28 \pm 3.10$ & $83.44 \pm 1.36$ & $\mathrm{P}>0.05$ \\
\hline $\begin{array}{c}\text { SBP } \\
\text { (mm of } \\
\text { Hg) }\end{array}$ & $124.96 \pm 0.924$ & $124.44 \pm 0.952$ & $\mathrm{P}>0.05$ \\
\hline $\begin{array}{c}\text { DBP } \\
\text { (mm of } \\
\text { Hg) }\end{array}$ & $84.08 \pm 1.07$ & $83.44 \pm 1.08$ & $\mathrm{P}>0.05$ \\
\hline \multicolumn{3}{|c|}{ Table 1: Comparison of Baseline and 3 months Post- } \\
intervention Parameters in Group A
\end{tabular}

Values represent mean $\pm S E,{ }^{*} p$ value as compared to baseline in same group, HR: Heart rate, SBP: Systolic blood pressure, DBP: Diastolic blood pressure.

\begin{tabular}{|c|c|c|c|}
\hline Parameters & $\begin{array}{c}\text { Baseline } \\
\text { Value }\end{array}$ & $\begin{array}{c}\text { 3 months Post- } \\
\text { Intervention }\end{array}$ & P Value* \\
\hline $\begin{array}{c}\text { HR } \\
\text { (per min.) }\end{array}$ & $84.56 \pm 1.003$ & $78.56 \pm 0.79$ & $\mathrm{P}<0.05$ \\
\hline $\begin{array}{c}\text { SBP } \\
\text { (mm of Hg) }\end{array}$ & $126.72 \pm 0.82$ & $119.92 \pm 0.67$ & $\mathrm{P}<0.05$ \\
\hline $\begin{array}{c}\text { DBP } \\
\text { (mm of Hg) }\end{array}$ & $86.84 \pm 0.83$ & $79.20 \pm 0.69$ & $\mathrm{P}<0.05$ \\
\hline \multicolumn{4}{|c|}{ Table 2: Comparison of Baseline and 3 months Post- } \\
intervention Parameters in Group B \\
\hline
\end{tabular}

Values represent mean $\pm S E,{ }^{*} p$ value as compared to baseline in same group

\begin{tabular}{|c|c|c|c|}
\hline Parameters & $\begin{array}{c}\text { 3 Months } \\
\text { Post- } \\
\text { Intervention } \\
\text { Group A }\end{array}$ & $\begin{array}{c}\text { 3 months } \\
\text { Post- } \\
\text { Intervention } \\
\text { Group B }\end{array}$ & P Value* \\
\hline $\begin{array}{c}\text { HR } \\
\text { (per min) }\end{array}$ & $83.44 \pm 1.36$ & $78.56 \pm 0.79$ & $\mathrm{P}<0.05$ \\
\hline $\begin{array}{c}\text { SBP } \\
\text { (mm of Hg) }\end{array}$ & $124.40 \pm 0.95$ & $119.92 \pm 0.67$ & $\mathrm{P}<0.05$ \\
\hline $\begin{array}{c}\text { DBP } \\
\text { (mm of Hg) }\end{array}$ & $83.44 \pm 1.08$ & $79.20 \pm 0.69$ & $\mathrm{P}<0.05$ \\
\hline \multicolumn{4}{|c|}{ Table 3: Comparison of 3 months Post-intervention } \\
Parameters in Group A and Group B \\
\hline
\end{tabular}

Values represent mean \pm SE, 3 months post-intervention comparison of $p$ value in Group A \& B.

\section{DISCUSSION}

Autonomic nervous system has profound influence on cardiovascular regulations in health and disease. (12) Vagal tone is an important determinant of cardiovascular health of an individual as it has profound influence on control of HR, BP \& CO. Persons with poor vagal tone are more susceptible to cardiovascular diseases such as MI, heart failure, and hypertension etc.(13) It appears that altered sympathovagal response is responsible for the premenstrual symptomatology. This may be due to shift of autonomic balance in favour of sympathetic system. As the parasympathetic activity is decreased, it may also be responsible for shifting of autonomic balance in favour of 
sympathetic activity and these ladies are unable to cope up with stressful situations. (14) Practising breathing exercises like pranayama is known to improve autonomic function by changing sympathetic or parasympathetic activity.

It has been suggested that well-performed slow yogic breathing decreases sympathetic activity during altitudeinduced hypoxia, by increasing oxygenation without altering minute ventilation.(15) Several researchers have reported that pranayama techniques are beneficial in treating a range of stress related disorders,(16) improving autonomic functions. (10)

In the present study, we observed effect of pranayama in females suffering from PMS. In our study, we compared HR, SBP, DBP before and after 3 months pranayama training in patients suffering from PMS. We concluded that subjects in group B have better control over their symptoms associated with PMS. We observed that in group B, HR, SBP, DBP showed significant reduction after the $3^{\text {rd }}$ menstrual cycle when compared with their basal level. Also, subjects in group B showed significant reduction in high basal sympathetic activity in comparison with group A.

There is possibility that the altered autonomic imbalance during the latter part of the cycle might be responsible for the causation of symptoms in susceptible individuals. This study was conducted to find the effect of pranayama in females suffering from PMS and outcome was that subjects doing pranayama were benefitted from this relaxation technique.

\section{REFERENCES}

1. Abraham GE. Nutrition and the premenstrual tension syndromes. J Appl Nutr 1984;36:103-24.

2. Reid RL. Premenstrual syndrome. Curr Prob Obstet Gynecol 1985;8(2):1-57.

3. Magos AL, Brincat M, Studd JW. Trend analysis of the symptoms of 150 women with a history of premenstrual syndrome. Am J Obstet Gynecol 1986;155(2):277-82.

4. Smith S, Schiff I. The premenstrual syndrome-diagnosis and management. Fertil Steril 1989;52(4):527-43.
5. Wyatt KM, Dimmock PW, Jones PW, et al. Efficacy of vitamin B-6 in treatment of premenstrual syndrome: systematic review. BMJ 1999;318(7195):1375-81.

6. Coppen A, Kessel N. Menstruation and personality. Brit J Psychiat 1963;109(463):711-21.

7. Reid RL, Yen SS. Premenstrual syndrome. Am J Obstet Gynecol 1981;139(1):85-104.

8. Matsumoto T, Ushirayama T, Moritani T. Autonomic nervous system in late luteal phase of eumenorrheic women with premenstrual symptomatology. J Psychosomatic Obst Gynaecol 2006;27(3):131-9.

9. Subbalakshmi NK, Saxena SK, D'Souza UJA. Immediate effect of nadi shodhana pranayama on some selected parameters of cardiovascular, pulmonary and higher functions of brain. J Physiol Sci 2005;18(2):10-6.

10. Pal GK, Velkumary S, Madanmohan. Effect of short-term practice of breathing exercises on autonomic functions in normal human volunteers. Indian J Med Res 2004;120(2):115-21.

11. Sivanand S. The science of pranayama. $4^{\text {th }}$ edn. Uttar Pradesh: A Divine Life Society Publication 1998.

12. Coupe M, Fortrat JO, Larina I, et al. Cardiovascular deconditioning: from autonomic nervous system to microvascular dysfunctions. Respir Physiol Neurobiol 2009;169(Suppl 1):S10-2.

13. Karthik S, Pal GK, Nanda N, et al. Sympathovagal imbalance in thyroid dysfunctions in females: correlation with thyroid profile, heart rate and blood pressure. Indian J Physiol Pharmacol 2009;53(3):243-52.

14. Kulshreshtha M, Kumar Y, Agarwal V, et al. Sympathovagal imbalance in premenstrual syndrome. Indian J Physiol Pharmacol 2013;57(4):443-7.

15. Bernardi L, Passino C, Wilmerding V, et al. Breathing patterns and cardiovascular autonomic modulation during hypoxia induced by simulated altitude. J Hypertens 2001;19(5):947-58.

16. Brown RP, Gerbarg PL. Sudarshan kriya-yogic breathing in the treatment of stress, anxiety, and depression. Part II-clinical applications and guidelines. J Altern Complement Med 2005;11(4):711-7. 